\title{
Urban Solid Waste Management And Environmental Sustainability In Abakaliki Urban, Nigeria
}

\author{
Joseph Okwesili, PhD \\ Department of Political Science, Ebonyi State University, Abakaliki \\ Ndukwe, Chinyere (Mrs), PhD \\ Nwuzor, Chidi Iroko \\ Department of Public Administration, Ebonyi State University, Abakaliki \\ doi: 10.19044/esj.2016.v12n23p155 URL:http://dx.doi.org/10.19044/esj.2016.v12n23p155
}

\begin{abstract}
Waste management has become a common issue of discourse among individuals, groups and governments. This study which assessed urban solid waste management in Ebonyi state with focus on Abakaliki urban specifically sought to find out why indiscriminate solid waste disposal/dumps has persisted in Abakaliki urban, investigate the measures put in place to curtail the tide and ascertain the extent to which indiscriminate waste disposal affects people's health and environment. Four null hypotheses were formulated and Human Capital Theory was adopted as the theoretical framework. The study used survey design whereby data were collected from the sample considered to be representative of the population. Taro Yameni's formula was applied to reduce the initial population of 116,987 to a smaller researchable size of 399 while data were collected through structured questionnaire. The data collected were presented in tables containing frequencies of the responses and their corresponding percentages. The four hypotheses of the study were tested using chi-square $\left(\mathrm{X}^{2}\right)$ statistical tool and the result of the analyses revealed that: there is currently no government approved dumpsites in Abakaliki metropolis, most communicable diseases are contracted from dirty environment, among others. The implications are that most households will soon be cut off by flood arising from the blockage of water channels, some streets and roads will be blocked by heaps of wastes and more epidemics will be contracted by the people if nothing urgent was done. The study concluded that, the Ebonyi State Environmental Protection Agency (EBSEPA) currently have no required manpower, technical skills and competences to curtail the tide of waste and therefore made the following recommendations: Ebonyi state government should strengthen the already established departments of
\end{abstract}


Environmental and Health Sciences in Ebonyi State University (EBSU) and the School of Health Technology, Ezzamgbo, by providing and equipping them with modern waste management equipment for students to be exposed to practical methods of waste management, Government should contract foreign-based private firm through Public-Private-Partnership (PPP) arrangement to establish waste management industry in Ebonyi state, immediate provision of permanent waste dumpsites by the government, among others.

Keywords: Assessment, Urban, Solid Waste Management, Nigeria, Abakaliki, Ebonyi State

\section{Introduction}

Waste often generated by human beings since time immemorial has continued to be a threatening problem and a growing one that is of major concern to every nation of the world. In Nigeria today, among the pressing environmental and public health issues are the problems of solid waste generation, control and disposal. Although the problem of solid waste disposal is as old as man's existence that is inextricably linked to the generation of waste, the truth is that in many cities, it has become so intractable that even the government is overwhelmed (Jimoh, 2005, Momodu, Dimuna and Dimuna, 2011).

Waste in the words of Douglas (2004) is any unwanted and discarded material that arises from the activities of humans and animals on earth. For Onwughara, Nnorom and Kanno (2010), Urban Solid Waste (USW) covers a broad range of materials including garbage, refuse from factories, commercial refuse, construction and demolition debris, dead animals and abandoned vehicles, food particles, plastics, bottles, polythene material (nylon bag), metallic objects, furniture/wood material, paper and some other unclassified wastes. Rodgers (2011) submits that waste management is a systematic control of the generation, storage, collection, transportation, separation, processing, recovery and disposal of waste.

In pre-industrial times, when population was small, waste was disposed on the ground, thrown into water, burnt or thrown into pit where it would turn to compost manure to improve soil fertility. From history, man is believed to have always adopted dumping, burning, manual recycling and waste minimization as waste management strategies with less than proportionate result in terms of cleaner and healthier environment. One can therefore say that human development or growth has been intrinsically tied to the management of waste, apparently due to its effects on public and environmental health, (Chukwuemeka, Ugwu and Igwegbe, 2012, and Ndinwa, Akpafun and Chukwuma, 2012). 
Today, due to rapid industrialization, increase in population and urbanization, the generation, disposal or management of waste has proved to be a major environmental and public health issue. This experience is always so, especially in developing countries like Nigeria where there is lack of or inappropriate strategies for managing wastes. Urban waste management today has become an intractable environmental problem that can be likened to a monster staring everybody on the face.

Solid waste dumps apart from its gory sight that destroy the aesthetics (beauty) of the environment have always affected the people's health by decomposing to produce provoking odour or contaminating our drinking water. This no doubt, causes avoidable epidemics.

This was what promoted the federal government of Nigeria to promulgate decree 58 for the establishment of Federal Environmental Protection Agency (FEPA) on 30 ${ }^{\text {th }}$ December, 1988 (Momodu et al (2011). A National Policy on the Environment was also formed to secure for all Nigerians a quality of environment adequate for their health and well being.

This was immediately followed with compulsory monthly environmental sanitation that takes place simultaneously nationwide, all things being equal, till today on every last Saturday between the hours of 7am-10am, Agunwamba (1998) cited in Momodu et al (2011). He submitted that in spite of the formulation of FEPA and a national environmental policy, the environment has not been adequately protected.

It should be recalled that, prior to the creation of Ebonyi state in 1996, Abakaliki urban was faced with myriad of environmental problems ranging from inadequate environmental education and awareness campaign to poor personal and environmental hygiene. Every street was adorned with heaps of refuse while Iyiokwu and Iyiudele rivers, in Abakaliki urban were converted to dumping arena for domestic wastes and human excreta. It is on record that the World Youths Soccer Championship slated for Nigeria in 1995 was cancelled because of the outbreak of cholera (a product of filthy environment) in Abakaliki (Uka, 2013).

It was in response to the foregoing realities in Ebonyi State upon its creation in 1996, that prompted the government to set up the Ebonyi State Environmental Protection Agency (EBSEPA) on $6^{\text {th }}$ December, 1996, to clean, protect and conserve the environment. While it cannot be denied that for quite some time, Ebonyi State Environmental Protection Agency (EBSEPA) as a state government agency has always embarked on some routine clearance of wastes, especially in the capital city (daily, weekly and monthly), provision of plastic dustbins for waste collection and evacuation, stationing of waste collection trucks in strategic places within the metropolis and its suburbs, house-to-house sanitary inspection and waste collection, the intractable nature of urban wastes always noticeable in Abakaliki urban 
leaves much to be desired especially as the local government whose constitutional responsibility it is to properly dispose and control these wastes, have been doing nothing. This has been why the commonly repeated experience is a simple transfer of refuse from one point to another in open trucks to some undesignated sites where they are either burnt or buried (Onwughara et al, 2010 and, Nkwede and Nwuzor, 2015).

The problem of solid waste generation, control, especially, disposal or simply, management, has continued to be a threatening global and environmental health issue but more pronounced in developing countries like Nigeria. In fact, Nigeria's major urban centres including Abakaliki are today grappling with the problems caused by indiscriminate heaps of solid wastes from the environment. This is despite the continuous government and individual efforts including daily, weekly or monthly environmental sanitation. Waste disposal habit of the people, lack of experienced and skilled manpower, inadequate/lack of modern plant and equipment, among others, militate against any waste management effort/strategy in Nigeria, particularly in Ebonyi State metropolis (Abakaliki urban). The failure of relevant agencies to stem the tide of reckless waste dumping and littering of our capital city and surrounding bushes indicate a clear pattern of non enforcement or non/poor implementation of existing environmental sanitation laws (Momodu et al 2011). Unfortunately too, the concerned local governments whose constitutional responsibility it is to properly collect and dispose of these wastes (refuse) have either forgotten or consciously neglected their duties.

Residents of Abakaliki urban are today apprehensive of epidemic outbreak as refuse takes over the metropolis. Indeed, heaps of refuse have become common sights along major roads, streets, common markets and at bus stops within the state capital prompting residents to express fear that the situation can lead to an avoidable epidemic outbreak if urgent steps were not taken by relevant stakeholders to ameliorate the situation.

For instance, in February, 2015, six (6) cases (two in Abakaliki and four in Ebonyi local government areas of deaths were reported as a result of the cholera outbreak in the areas. About eight (8) patients were said to be hospitalized and were in critical conditions and in the words of the then Ebonyi State Director for Public Health, Dr Chris Achi, it was as a result of the intractable nature of filthy environment which Abakaliki urban centre has been found in, (Uka 2013).

Although Ebonyi State government has always claimed to have imported some machines to be used in waste management including promising and paying the contractors on actuality bases, the truth is that such machines/equipment if any, have not been seen to be doing anything especially as there is still no matching manpower skills and intelligence to 
manipulate them even among the Ebonyi State Environmental Protection Agency (EBSEPA) staff as the agency is statutorily and structurally deficient in that regard.

Therefore, the persistent increase in the number of indiscriminate solid waste disposal/dumps despite the provision of the customized Ebonyi State Environmental Protection Agency (EBSEPA) waste bins/stationary trucks which has continued to affect people's health and environment in Abakaliki urban without any concrete management strategy in place necessitated this research. The broad objective of the study was to assess solid waste management in Abakaliki urban. Specifically, the study sought to:

Find out why the number of indiscriminate solid waste disposal/dumps has continued to increase in Abakaliki urban despite the provisions of the customized Ebonyi State Environmental Protection Agency (EBSEPA) waste bins/stationary trucks.

- $\quad$ Investigate measures already put in place to ensure that the Ebonyi State Environmental Protection Agency (EBSEPA) equipment curtail the tide of indiscriminate solid waste dumps in Abakaliki urban.

- Ascertain the extent to which indiscriminate solid waste disposal/dumps have contributed to health complications suffered by the people in Abakaliki urban.

- $\quad$ Ascertain the number of ways in which indiscriminate solid waste disposal/dumps affect the Abakaliki urban environment.

\section{Conceptual Clarifications}

\section{The Concept of Waste and Waste Management}

The concept of waste has attracted a wide range of interpretations from both scholars and the general public. This is because; it is already a monster that has a negatively far-reaching consequence on the life of the people. All definitions of waste more often, point to its useless or harmful nature.

Wikipedia, the free online dictionary, defines waste as any unwanted or unusable material, that is, any substance which is disposed after primary use, or it is worthless, defective and of no use while Oxford Advanced Learner's Dictionary, Special Price Edition (1998), agrees with Wikipedia that waste is any material, food, etc that is no longer needed and is to be thrown away. The United States Environmental Protection Act (EPA) 1990, agreed to the dictionary definition when it states inter alia that:

a. Waste is any substance which constitutes a scrap material or an affluent or unwanted surplus substance which requires being disposed.

b. Any substance or article which requires be disposing off as broken, unwanted, and worn out, contaminating or otherwise, spoiling. 
For Oyideran (1997), wastes are substances or objects discarded as worthless or unwanted, defective or of no further value from manufacturing or production process. Madu (2001) in Ezeani and Elekwa (2001), however noted that the manner in which human settlements dispose off their wastes and even the degree to which they declare certain physical outputs of production and consumption processes to be waste, reflect level of development of the settlement. According to Scott (1996), they reflect a series of social choices, with consequences of those choices on the environment varying widely.

One discerning truth from the definitions of waste is that, generally, it possess a significant different threat to human health or environment, this is not unconnected with the manner in which it may be disposed off and partly because, the holder no longer has the same sense of obligation in relation to it.

Although wastes are inevitable consequences of human activities that are either a byproduct of initial production process or arise when objects or materials are discarded after they have been used, care must be taken in defining wastes so as not to make hasty generalization. Attah (2013:4) suggests four broad categories which may be considered in deciding the question of whether an object is a waste:

i. Worn out but functioning substances or objects, which are still usable (albeit, after repair) for the purpose for which they were made are not to be considered waste.

ii. Substances or objects which can be put to immediate use or otherwise by a specialized waste recovery operation or undertaking are likewise not to be considered waste.

iii. Degenerated substances or objects which can be put to use only by establishments or undertaking are not waste.

iv. Substances which the holder does not want and which he has to pay to be taken away are wastes.

The definitions recognize the usefulness of waste through proper management. But they are only suggestive and would actually be meaningless except to waste disposal and management agencies like EBSEPA who are interested in their fees for collection and disposal. It should be noted that no town in Nigeria especially in urban and semi-urban centre of high population density can boast of having found a lasting solution to the problem of filth and huge piles of solid waste rather the problem continues to assume a monstrous dimension (Okpala 1986; Mba, 2003).

In the words of Udechukwu in Chukwuemeka, et al (2012:352), wastes are useless, unwanted and discarded materials. WHO in Ndinwa, Akpafun, Chukwuma, Osubor and Nwakaego, (2012:30) corroborated Udechukwu when they refer to waste as 'something which the owner no 
longer wants at a given time and space and which has no current or perceived market value”. They went further to argue that the line of thought in the definition presented a broad based approach towards the classification of what constitutes waste and so remarked that what one regards as waste may not be totally useless as much can be recycled to produce new products.

A material to them is only described as a waste if nothing can be done further to convert them to other good uses. But, this maybe far from the truth in that substances, objects or material which can be managed for productive uses, can constitute a serious health problem before it is recycled. For Oyeniyi (2011:4), waste is capable to different interpretations and meaning. According to him:

Waste could be any material which has been used and is no longer wanted, for example, because the valuable or useful part of it has been taken out. Waste could also mean an opportunity not taken i.e. when one does not take an advantage of an opportunity when it is available... from these and many more ways through which the term could be understood or used, it is the first sense as any material which has been used and is no longer wanted, because the valuable or useful part of it has been taken out.

This definition is defective in that it fails to recognize any possibility of converting waste to other good uses including fertilizers, humus and the likes. Many scholarly definitions of wastes seem to point to the non-usability of such discarded material. In the words of Attah (2013), waste is something that is not or no longer useful and is to be thrown away or disposed of or any material lacking direct value to the producer and so must be disposed off. The later definition can be more acceptable in that waste unless otherwise used, lacks immediate or direct value.

For the purpose of this study, we conceptualize waste as any material or substance that is intentionally or otherwise discarded by the owner which lacks current value until properly managed and which is capable of negatively affecting peoples' lives and environment or simply put, waste is any damaged, defective, superfluous, unwanted by product or material produced from places of human or animal habitation and which is very hazardous to human health and environment if not properly managed.

\section{The Concept of Waste Management}

The concept of waste management has attracted a lot of attention from researchers, scholars and the general public. In Nigeria today, the issue is so burning that the government seem to be helpless on the best alternative measure or strategy to be adopted to curtail the tide of waste. This is because, apart from the horror sights that these wastes create in our urban centres, 
their negative health and environmental consequences (effects) are always far-reaching.

Bridgewater (1980) and Ezema (2009) in Chukwuemeka et al (2012) argued that waste management was not a serious problem in the early preindustrial times because the population was small and wastes generated, insignificant. According to them, common wastes produced during early ages were mainly ashes and human wastes; these were released back into the ground, which did not cause any harm to the environment. In the words of Chukwuemeka et al (2012:154):

"With the advent of industrial revolution, waste management became a critical issue. This was owing to the increase in population and massive shifts in population from rural areas to industrial towns and cities during mid $18^{\text {th }}$ century. There was a consequent increase in industrial and domestic wastes posing threat to human health and environment”.

However, the submissions of Chukwuemeka and others that increased urbanizations and industrialization were the major causes of waste management challenges, were vehemently criticized by Adejobi and Olorunnimbe, 2012, Tobore, 2013 and Attah (2013) when they argued that the volume of waste generated do not actually constitute the major environmental problem but rather, the inability of governments, individuals and waste management/disposal agencies to keep up with the task of proper and efficient management of waste. This also is defective in that it lacks specificity on how or where government should concentrate.

Waste management simply means the collection, keeping, treatment and disposal of waste in such a way as to render them harmless to human life and the environment in general, Attah (2013). He went further to conceptualize waste management to be the organized and systematic dumping and channeling of waste through or into landfills or pathways to ensure that they are disposed off with attention to acceptable public health and environmental safeguard. He concluded that proper waste management will result in the abatement or total elimination of pollution.

Attah's understanding of waste management to mean a situation where waste is removed in such a way as to avoid its health and environmental harm, has some elements of truth but one-sided. This is because, disposal or evacuation as his definition suggests, is only an aspect of management. Burning, burying and the likes, reduce the health and environmental effects of waste, but they are not complete management in themselves since waste is said to be managed if apart from the foregoing, it is utilized to serve another purpose or add marginal utility.

Rodgers (2011), quoted in Chukwuemeka et al (2012), contends that waste management is a systematic control of generation, storage, collection, 
transportation, separation, processing, recovery and disposal of solid waste. This definition address critical processes of solid waste management but, it is selective as the only emphasis is on solid waste. It should be noted that other wastes including liquid and gas can be converted or managed to serve valuable uses.

Waste must not always be seen as something that is completely valueless or rubbish that must be discarded, but as something which when properly managed can create wealth. In line with this, Nwude, Igboro, Umar and Okuofu (2006:85), advised that:

"Waste should not be regarded as something to be thrown away or disposed off, but as raw material. So, like the biosphere, all wastes generated by industries or consumers should be put back into the industrial economy as much as

possible. This is what recycling or management is all about.

Sridhar (2006), in agreement with Nwude et al, noted that waste management is at once a technical, cultural and financial problem and so involves various steps including; collection, transportation and recycling. To him, this will help in waste minimization or reduction. It should be noted that waste recycling as a strategy for waste management, will as much as possible guarantee waste to wealth options.

It is timely to point out that waste management is an aspect of environmental management or sustainability which can be interpreted as a conscious and systematic effort by one or more persons acting in concert to produce an aesthetically pleasing, economically viable and physically healthy environment. This may be why Oyediran (1997), defined waste management as the collection, transportation, storage, treatment and disposal of wastes including the after care of the disposal site. It also comprises all administrative, financial, legal and planning functions, as well as, the physical aspects of solid waste handling, Madu (2001). Nwokocha (2012) has in a summarized tabular form, assigned percentage (\%) to people's six (6) different interpretations of waste and waste management thus:

Nwokocha's percentage (\%) definitions of solid waste and solid waste management.

\begin{tabular}{cccc}
\hline S/n & Waste & Waste management & $\%$ \\
\hline 1. & $\begin{array}{c}\text { Unwanted } \\
\text { materials } \\
\text { Useless objects }\end{array}$ & $\begin{array}{c}\text { Collection and throwing away any unwanted material from } \\
\text { people's houses. }\end{array}$ & $\begin{array}{c}\text { Burning/burying of useless objects/substance to avoid } \\
\text { environmental and health harm }\end{array}$ \\
2 & Garbage & $\begin{array}{c}\text { Recycling and incineration of garbage to create wealth } \\
\text { Decomposing every rubbish into humus to be used as organic }\end{array}$ & $\begin{array}{c}22 \\
\text { fertilizer }\end{array}$ \\
3 & Rubbish & Fumigating dirt's to prevent communicable diseases. & 16 \\
5 & Dirt & Effective and efficient processing of refuse to create wealth & 18 \\
\hline 6 & Refuse & & $100 \%$
\end{tabular}


For us, waste management is a calculated, conscious and timely efforts made through variety of measures/techniques or strategies by individuals group(s), agency or government to effectively generate, sort and dispose waste for better uses and still preserve and protect the people's health and environment. Simply put, waste management implies any strategy or method that will nip waste in the bud by eliminating its harmful effects and making it useful to man.

\section{The Nature and Sources of Urban Solid Waste}

Wastes can appear in different forms or nature. They may be classified in terms of origin, physical forms or physio-chemical properties (Madu, 2001). Accordingly, wastes may be described as solid or sludge, airborne particles or dust, liquids or affluent and gases. On the basis of origin, Oyediran (1997:96) identifies six classes of waste as follows: Municipal/urban waste (comprising residential, institutional and commercial); Agricultural wastes; Mining and mineral wastes; Industrial wastes; Miscellaneous wastes

Some wastes in their very nature, can best be described as toxic and/or hazardous. The definitions of toxic and hazardous waste are imprecise and are frequently used interchangeably (Diribe, 1990). However, toxic waste is a relatively limited concept, referring to materials that can cause death or serious injury to humans and animals. Hazardous waste on the other hand, is a broader term referring to all wastes including toxic ones that pose an immediate or long term health risk or that endanger the environment (Emeribe, 2000).

A visible feature of most urban centres (Abakaliki inclusive) in Nigeria today are the refuse mountains which often take over parts of motorable roads and streets, build up on river banks and swamps, emit foul odours as well as serve as breeding grounds for pathogenic agents and preventable diseases. These mountains of heterogeneous wastes have not been cleared in some towns for many months due to lack of removal trucks (Akinbode, 2002). Consequently, the Nigerian urban environments are severely degraded and are characterized by unacceptable and rapidly rising insalubrities, health hazards and aesthetic degradation. In a similar vein, Phil - Eze (2001:195) submitted that in Nigeria:

The most visible urban environmental problem that confronts a first time visitor is waste accumulation and inadequate disposal methods. The wastes are generated from variable sources such as residual areas, commercial areas, industrial areas and institutional establishment. The wastes, which are either liquid or solid in nature, may also be either biodegradable or non-biodegradable. 
What is understandable is that irrespective of the nature or form of waste i.e. solid or liquid, it creates serious urban environmental problem. For instance, solid wastes block drainage in urban centres, block roads to impede free flow of traffic and issue out offensive odour as the wastes undergo decomposition. Asuquo, Kinuabeye and Atu (2012) classified wastes as garbage, vegetable, paper/glass, wood/bone cans and plastics. They however did not recognize the liquid and gaseous wastes that always have serious health implications.

Some scholars believe that urban wastes are quite different from other wastes because of their visible effects. For Sharma (2010), urban wastes are those materials that are generated, used and have no further value and are thrown away in the environment but which can be valuable raw materials located at a wrong place. The definition is strategic in that it believes that wastes can still be converted to other uses.

Gordon (2005) is of the view that urban solid wastes are commonly known as trash or garbage, it is a combination of the entire city's solid and sometimes semi-solid wastes. He categorized urban wastes into five types, viz: The biodegradable which includes things like food, and kitchen wastes such as meat trimmings or vegetable peelings, yard or green waste and paper, Recyclable materials: these include non degradable items like glass, plastics, bottles, other plastics, metals and aluminum cans, Inert waste: inert materials which include construction and demolition waste are not necessarily toxic to all species but can be harmful to humans, Composite waste: Items composed of more than one material such as clothing, plastics as well as children toys, House hazardous: this includes medicines, paints, batteries, light bulbs, fertilizers and pesticides containers and electronic wastes (e-wastes) like computers, computers and cellular phones. His classification never talked of liquid wastes such as used or contaminated water, animal urine and the likes that can cause cholera when the odour is inhaled.

Wastes can be sourced from places of human and animal habitation and environments. Douglas 2004, Udechukwu, 2009, Ndinwa et al (2012), observe that waste composition in urban centres comprise of leaves, contaminated water, polythene bags, paper, food waste, tins, metal, glass, rags and so on, most which decompose to produce a very disturbing odour.

It is important to note that every urban dweller contributes to increasing the volume of wastes in the city daily and that is why domestic and commercial sources of wastes have grown significantly in Nigeria over the years. Every time a householder shops at the market, store and open market, he contributes to the mount of wastes and so, it is even possible to quote figures which show that the production of waste amounts to millions of tons (Attah, 2013). He went further to state that waste is usually classified according to (a) its sources (b) its harmful effects on humans and 
environment (c) the control which are appropriate to deal with it. Be that as it may, it has to be pointed out that while some wastes are organic and can decay example, food, and decomposed into the soil, others are inorganic, example, tins, cannot decay or decompose.

In their holistic explanation of the nature and sources of urban wastes, Sridhar and Hammed (2014), argued that there are variety of wastes, liquid or solid, emanating from human activities (domestic), agricultural or industrial activities (neither domestic nor hazardous) and hazardous or special faeces. Among the liquid wastes are the sewage, sullage and so on.

Summarily, we conceptualize urban solid wastes to mean a combination of the entire city's wastes in their hard nature including domestic, (food particles, leaves), industrial (tiles glasses rods, iron etc) and commercial (papers etc) discharges which are disposed/dumped, most times, indiscriminately to the disposed/dumped of human health and environment.

\section{Methods of Solid Waste Disposal in Nigerian Urban Centres}

Historically, waste generation which lead to disposal is a normal and inevitable consequence of human activities. In primitive Nigerian rural areas for instance, where people live in their natural state, the smallness in population and the volume and nature of wastes generated do not pose a serious challenge in terms of its disposal. Such wastes were thrown into pits to decompose as compost manure, given to domestic animals, burnt or thrown into running waters (Okpala, 1997, Oyediran, 1997, Barry and Ekpoh, 2003, Edu 2003, Sule, 2004, Asuquo et al 2012 and Chukwuemeka et al, 2012). In their observation, Nkwede and Nwuzor (2015:3) point out that:

Waste disposal system in Abakaliki urban does not follow the latest $21^{\text {st }}$ century method to convert waste to wealth. This has been why the commonly repeated experience is a simple transfer of refuse from one point to another in open trucks to some undesignated sites where they are either burnt or buried... so, waste disposal and not waste management is generally practiced.

The methods as so identified are capable of exposing residents to health risks since some of the wastes may have decayed thus, releasing some unpleasant odours. For Nabegu (2013) and Butu and Mshelia (2014), urban wastes are generally disposed or dumped along major streets at close proximity to the houses and public places and some close to the river where they block free flow of water from their channels. It has to be noted that these experiences of indiscriminate waste disposal is despite the fact that trash or waste bins are strategically provided by the various state environmental protection agencies in few areas and along major roads. More 
than two third of the residents do not use authorized dumpsites for their waste (Nabegu, 2013).

The practice of disposing urban solid wastes indiscriminately in the words of Butu, Ageda and Bichi (2013) and Omole and Alakinde (2013), has a price to pay in terms of collection, transportation and disposal costs and loss of valuable raw materials (recyclables, reusable and repairable) and the impact on the environment due to air, water and soil pollutions and associated health risks that ultimately impact the economic sustainability, and this no doubt, can lead to more environmental degradation in our urban centres and for an urban centre like Abakaliki where government is still battling to provide the basic social amenities and not waste management, heaps of refuse may soon become a norm.

Asuquo et al (2012) had while studying the methods of waste disposal in Calabar, Cross River, Nigeria, observed that urban dwellers dispose their wastes in waste cans (64\%) their backyards (17\%), Gutters, pit, open spaces and road sides. A peep into their observations reveals that the methods are conventional and general practice in almost all the Nigerian urban centres especially as various state governments seem to be overwhelmed with the ever-increasing heaps of refuse dumps. This no doubt exposes people to avoidable health risks. More often than not, what we see in most of our metropolis is the phenomenon of residents evacuating their wastes manually to the areas (un)designated as dump sites like Water Works Road by CAS in Abakaliki, Ebonyi state. Very few of them use truck, bike or wheelbarrow as the case may be (Sule, 2001). At times, people use the night as the safest time to drop their wastes on the roads so that they cannot be seen.

The term waste disposal in all its ramifications encompasses all steps taken in controlling the generation, transportation and discharging of waste in a sanitary manner (Isaac and Olanike, 2007, Ogwueleka, 2009 and Atta, 2013). The definition is a pointer to the fact that disposal of waste is mostly undertaken to reduce their effect on health, the environment or aesthetics. Sustainable waste disposal system it should be noted provides a comprehensive inter-disciplinary framework for addressing the problems of managing urban wastes and so upgrading the modern waste disposal system and services and increasing their efficiency is a precondition for improving the environmental quality of the urban centres.

It should be noted that the most frequently used disposal methods in Nigeria like the provisions of the customized EBSEPA waste bins/stationary trucks in Ebonyi State for disposing or dumping the wastes is never the problem but that they are never targeted at dumping wastes in a particular place for productive use. For instance, waste dumping is the common practice in Nigeria. The wastes have often been seen as indiscriminately 
dumped on open plots of land and particularly on streets. This method is based on "throw away culture" in which wastes are disposed into the nearest open space, on land or surface water without environmental consideration. In fact, this reflect what is referred to as not in my backyard syndrome" whereby the waste is merely transferred from a location to another location where its nuisance value is thought to be less (Okpala, 1997, Oyeniyi, 2011 and Tobore, 2013).

In Abakaliki urban centre for instance, sometimes, the wastes are burried or used in landfills, hoping that out of sight is out of mind but the later effects are always more severe. Waste burning or incineration, composting and recycling, as methods of disposing solid wastes in Nigeria have been seen as inadequate and cannot covert wastes to proper uses.

\section{Some Communicable Diseases Associated with Solid Wastes in Nigeria}

Fly borne diseases

Rodent borne diseases

Mosquito born diseases
Typhoid, dysentery, diarrhea, salmonellae, cholera, meioses, yaws, tuatara, sand fly fever, helm in thiasis.

Lasers fever, Ebola diseases, Histoplasmosia, dermatitis, rat tapeworm, virus infections, leptospirosis, relapsing fever rickethacal pox, plague.

Malaria, yellow fever, dengue, encephalitis, filariasis etc.

Source: Federal Ministry of Housing and Environment: the state of environment in Nigeria (1982), Quoted in Ologbobo (1997) and Madu, (2001).

Ngoka (2001) laments that solid wastes block drainages in urban centres, block roads to impede free flow of traffic and issue offensive odour as the wastes undergo decomposition. It equally degrades the aesthetic value of the urban landscape because of its unclean condition. Attempts to reduce the volume of solid wastes for instance by burning will definitely pollute the air thereby causing air born diseases, while disease vectors visit the waste dumps, acquire aspects of the disease pathogens and infest nearby residents with such health hazards. Sewage from waste dumps on the other hand, pollute surface and underground water, while liquid wastes (effluents) from industries even cause more damage.

In Abakaliki urban for instance, the ugliness of most streets has become an eye sore and the offensive odour is one that has made some residents to conclude that odour-free streets in Abakaliki will not be achievable. Most serious and often unrecognized is the transfer of pollution to waste, which occurs when the leached from a refuse dump enters surface or ground water. For Srihar and Hammed (2014), the environmental impacts of wastes can be clustered into six categories which include; global warming, photochemical oxidant creation, a biotic resource depletion, acidification and entrophication. In fact, the truth of the matter is that refuse generation and its likely effects on the health, quality of environment and the urban 
landscape have become burning national issue in Nigeria today. On the environmental and health consequences of wastes, Butu and Mshelia (2014:9) observe that:

If the solid wastes are not managed properly, decomposition and putrefaction may take place, causing land and water pollution when the waste products percolate down into the underground water resources. The organic solid waste during decomposition may generate obnoxious odours. Stray dogs and birds may sometimes invade garbage heaps and may spread it over the neighbourhood causing unhygienic and unhealthy surroundings.

Obviously, urban unmanaged solid waste can cause climate change which results when heaps of solid wastes decompose to emit methane "greenhouse gas" that is more potent than carbon chioxide, (Butu and Mshelia, 2014). This methane contributes to global warming which could result into climate change as a result of destruction of ozone layer (Sharma, 2010) quoted in Butu and Mshelia (2014). Abakaliki urban residents are more often than not, confronted with the hazardous impact to their collective health and safety. The hue and cry over the health consequences of exposed and fermenting rubbish have not been quantified, although their impacts are noticeable, especially in times of epidemic like the recent outbreak of cholera that claimed the lives of tens of Abakaliki urban residents.

\section{Assessment of the Efforts towards Waste Management in Nigeria}

If there is any problem in which both the government and individuals are tired of, confused and losing sleep about in Nigeria, it is squarely and mainly that of environmental wastes. Nigeria's major urban centres are today fighting to clear mounting heaps of solid wastes from their environments. Nigerian government since independence has been mapping out strategies and making different efforts towards curtailing the tides of the everincreasing wastes in its urban centres but with little or no appreciable results.

The Nigerian government being aware of the need for high quality urban environment accordingly made bold attempts at improving urban environmental management. In the first place, Nigeria is committed to a national policy that ensures sustainable development based on proper management of the environment in order to meet the needs of the present and future generations (Federal Republic of Nigeria, 1990). To achieve this laudable objective, the Federal Environmental Protection Agency (FEPA) was established in 1988 and was charged with the responsibility of setting, monitoring and enforcing national environmental quality standards (Madu, 2001). It was also authorized to handle all forms of environmental problems and formulate policies dealing with them (FEPA 1989 cited in Madu, 2001). 
FEPA has now been scrapped and its activities incorporated in the Ministry of Environment. Dimuna (2004:132) noted that:

Specifically, the national guidelines and standards for environmental pollution and control of 1991 and the pollution abatement in industries and facilities generating waste regulation also of 1991 stipulate guidelines for the design, construction, maintenance and operation of landfill and the requirements for landfill permit. On the other hand, the Environmental Impact Assessment (EIA) decree 86 of 1992 makes it mandatory for new major projects (including waste disposal facilities) to undertake EIA.

Some states including Ebonyi, have implemented the monthly clean up exercises to the later including setting up mobile environmental courts to try defaulters but our urban cities have been overwhelmed by indiscriminate wastes. Ebonyi state governments through EBSEPA has gone to the extent of contracting some private firms with the mandate of ride of the city of wastes and are being paid on actuality basis.

The foregoing are evidences that Nigerian government at all levels have not been sleeping on duty in trying to keep the environment clean. The various planning and policy documents in Nigeria show that sufficient attention has been given to environmental policies and programmes and so, the persistent problem of environmental deterioration in the country must therefore be explained by the wide gap existing between policy goals and achievements. In every state for instance, there are state environmental protection agencies whose mandate it is to ensure clean and healthy environment for all inhabitants. In Ebonyi state, the agency is known as the Ebonyi State Environmental Protection Agency (EBSEPA).

\section{Challenges of Waste Management in Nigerian Urban Centres}

Literature abounds on the factors that challenge waste management efforts in Nigeria. While some argue that the factors are corporate, others believe they are individualistic, socio-cultural or even political. What is indisputable is that despite government and individual efforts at managing the ever-increasing wastes in Nigerian cities, the situation still seems intractable.

For Adejobi and Olorunnimbe (2012), the factors that hinder waste management are varied and can be political, socio-cultural, economic and environmental. On the political aspect, they argued that the relationship between the levels of government (federal, state and local) over power decentralization, affect the way and manner in which citizens can contribute to waste management. Socio-culturally, they submitted that waste management systems are influenced by the attitudes of the urban population 
which to them is that of "I don't care" attitude. Until urban waste management plan incorporates the served population, such effort will continue to be a wasted one. On the economic context, they observed that the willingness and ability to pay for a particular level of waste management service is dependent on the economy of the area in question as economic development determines the volume and composition of wastes generated. The structure of the environment can also influence waste management needs. This is because, the topography, conditions of roads, density and width to a large extent, will influence the selecting and/or designing waste collection procedures and equipment such as containers and vehicles (Adejobi and Olorunimbe, 2012). The manpower requirement, finance, population and equipment are some of the factors that can challenge any waste management effort. Adejobi and Olorunimbe (2012: 355-357) further summarized the challenges of waste management thus:

Solid waste management has been intractable problems beyond the capacity of most municipal/state government in developing countries especially with rapid and often haphazard urbanization, population explosion, the weak and inadequate infrastructure for waste management resulting in refuse heaps that is left to burning method and exposure on open landfills. Attitudinal problem of the public to waste as material to be thrown away is a social challenge, this coupled with lack of infrastructures for waste management (including roads, facility for waste collection, disposal and treatment, indiscriminate waste disposal on land, farms, surface waters, wetland) constitute technical challenges. Limited knowledge and understanding of the operational and managerial/maintenance aspects of waste management infrastructure in a conducive environment (management challenge) is also a problem. Lack of and/or inadequate legal and institutional/administrative framework for the environmentally sound management of waste, non domestication of multilateral environmental agreements on wastes and chemical, i.e. based Stockholm, Cofferdam conventions legal) is another problem.

Earlier, Momodu et al (2011) had lamented that despite the monthly national sanitation, exercise the face of our urban centres appear more deplorable as people are still more confused on where and how to dump their wastes. This according to them is a result of non-compliance and non conformance to existing laws and poorly coordinated urban solid wastes evacuation plan. Our markets, shopping malls, civic centre, residential and commercial areas are still defaced with heaps (mountains) of uncleared solid 
wastes. Local governments appear helpless on how to curtail the tide of solid wastes in their areas as they lack the capability and the technical knowledge to combat the menace. Individuals too are confused on where to dump their wastes (no known official dumpsites). In Abakaliki metropolis, "no dumping of refuse, fine, $\$ 500$, 1000 , 2000 , $\$ 5000$, etc are common sights for residents yet, no known approved dumpsite by government anywhere in the state. The truth is that, in Abakaliki, generation, collection, transportation and disposal of solid wastes do not follow any known standard. They are not sorted either as there is lack of technical knowhow to manipulate any waste management equipment when procured by government.

In the submission of Attah (2013), challenges to waste management in Nigeria and any part thereof, has nothing to do with appropriate legislations, rather inadequate funding, population explosion, lack of trained/professional waste managers, lack of effective monitoring and control, peculiarity of the Nigerians attitude and lack of modern technology/lethargy in implementing efficient waste management methods, etc are the bones of contention.

There is a high level of truth in what Attah is saying considering the fact that Nigerian government at one time or another over the years, has enacted many environmental sanitation laws which would have manifested in cleaner and healthier environment, but to no avail.

Tobore (2013) seemed to partly disagreed and partly agreed with Attah, when she summarized the challenges in waste management services delivery thus: Lack of comprehensive legal framework and enforcement of the existing regulations, Low investment (private) in infrastructure, and inadequate personnel, Wrong attitude of the public towards solid waste disposal, Financing - cost recovery is low in most states and no funding, Poor planning - low data management and uncontrolled urbanization, Uncoordinated institutional functions, Low academic research and industry, Lack of the needed political will.

For us, like many authors, a lot of factors can be identified as being obviously responsible for waste management challenges in Nigerian cities and Abakaliki urban in particular. Prominent among them is the lack of corresponding human capital (manpower) that can competently handle any waste management strategy or equipment. Others are poor budgetary provision for waste management agency, lack of standard waste management equipment, illegal dumpsites, open disposal of wastes, non-involvement of the people particularly the landlords in planning any waste management option, unplanned urban growth and development, poor attitude to waste disposal lack of political will on the part of government among others.

It should be noted that although plethora of literature were replete with the factors that were responsible for the challenges in waste 
management in Nigeria and its component parts with some recommendations, none was able actually enquire into human capital factor as to ascertain how its development could affect any effort towards waste management especially in Abakaliki urban, and that was the gap in knowledge.

\section{Methodology}

This study adopted human capital theory as its framework of analysis. Arthur Lewis is said to have begun the idea of human capital when he wrote in 1954 about the economic development with unlimited supplies of labour but it was first discussed by Arthur Cecil Pigou. According to this theory, the principal source of productive capacity or management whether in an economy or organization, rests in the capacity of the people and so, human capital has to do with the stock or a collection of resources - all the knowledge, talents, skills, abilities, experience, intelligence, training, judgment and wisdom possessed individually and collectively by people and which represents a form of wealth which can be used to overcome any challenge and directed to accomplish the goals of the nation or state or a portion thereof. Human capital is directly related to human development and effective and efficient uses of the wealth of nation, and so, where there is human development, the qualitative and quantitative progress of a nation or any part thereof is inevitable. This human resource can be transformed into human capital with effective inputs of education, health and moral values and the transformation of raw human resource into highly productive human resource with these inputs is the process of human capital formation.

Madu (2001) argued that human capital development is a sure-bet for solving any human or environmental issue that involves proper exploitation of the physical environment as solutions to human challenges revolve around human development. He stressed that human capital involves the skills, knowledge and intelligence required in tackling technical matters.

Since this research was more suggestive than reactive, the theory was applied through identification and suggesting the institutional framework and practical approach that can be used in managing the ever increasing wastes in Abakaliki urban centre.

Although one may want to criticize this theory by pointing to the difficulty in measuring its key variables and how far their use can guarantee an advance in productivity, the theory was relevant for this study in that it was an avenue to open new vistas in making waste less harmful and more useful through proper management. It also uncovered the reasons for the dismal performance of government even through EBSEPA in waste management. This will surely give room for concerned stakeholders in waste management to fashion out new strategies that would be adopted or adopt the 
suggested strategies that will nip indiscriminate solid waste disposal in the bud in Abakaliki urban.

Also, the study adopted survey research design. This means that some carefully selected people were studied through collecting and analyzing data (primary-structured questionnaire) from them as they were considered to be the representatives of the population. The sample size of the study is 399 and it combined simple random, stratified and purposive sampling techniques. The simple random sampling ensured that every member of the population had equal and independent chance of being selected in the samples studied. Stratified sampling ensured that samples were divided into groups (strata) on the bases of their common characteristics, while purposive sampling ensured that the targeted respondents competently represented each stratum and quickly and objectively too, provided unbiased information about the issue under investigation. The respondents comprised some selected Landlords/caretakers, leaders of markets/traders associations, civil/public servants and carefully selected residents/occupants of the affected areas. In line with these, the researchers applied Bowley's Proportional Allocation Formula to determine the actual number of persons to whom questionnaire were administered in the study area.

Data collected in the field were analyzed using frequency distribution tables and simple percentage technique. But, in testing the hypotheses as to achieve the objectives of the study, the researcher used chi-square $\left(\mathrm{X}^{2}\right)$ statistical tool thus:

$\mathrm{X}^{2}=\frac{\sum(\mathrm{O}-\mathrm{E})^{2}}{\mathrm{E}}$

Where;

$$
\begin{array}{lll}
\mathrm{X}^{2} & = & \text { chi-square } \\
\Sigma & = & \text { Summation } \\
\mathrm{O} & = & \text { observed frequency } \\
\mathrm{E} & = & \text { expected frequency }
\end{array}
$$

\section{General Decision Rule}

If the calculated chi-square $\left(\mathrm{X}^{2}\right)$ value is greater than the critical value that is, degree of freedom at 3 , the null hypothesis is accepted as valid while the alternate hypothesis is rejected. 


\section{Test of Hypotheses}

Contingency Table drawn from the questionnaire distribution

Observed frequencies $(O)$ and their corresponding percentages

\begin{tabular}{|c|c|c|c|c|c|c|c|c|c|c|c|}
\hline \multirow[t]{2}{*}{$\mathrm{S} / \mathrm{n}$} & \multirow[t]{2}{*}{ Items } & \multicolumn{8}{|c|}{ Responses options (O) and their percentages } & \multirow{2}{*}{\multicolumn{2}{|c|}{ Total }} \\
\hline & & SA & $\%$ & A & $\%$ & $\mathrm{D}$ & $\%$ & SD & $\%$ & & \\
\hline 1. & $\begin{array}{l}\text { Lack of clear } \\
\text { knowledge and } \\
\text { skills to make } \\
\text { solid waste useful } \\
\text { is never the main } \\
\text { reason for the } \\
\text { persistent } \\
\text { increases in the } \\
\text { number of } \\
\text { indiscriminate } \\
\text { waste dumps in } \\
\text { Abakaliki urban. }\end{array}$ & 92 & 24.54 & 84 & 22.40 & 99 & 26.40 & 100 & 26.67 & 375 & 100 \\
\hline 2 & $\begin{array}{l}\text { None of the } \\
\text { measures already } \\
\text { put in place is } \\
\text { capable of } \\
\text { curtailing the tide } \\
\text { of indiscriminate } \\
\text { solid waste } \\
\text { dumps/disposal in } \\
\text { Abakaliki urban. }\end{array}$ & 269 & 71.73 & 21 & 5.60 & 70 & 18.67 & 15 & 4.00 & 375 & 100 \\
\hline 3 & $\begin{array}{l}\text { Most epidemic } \\
\text { outbreaks in } \\
\text { Abakaliki urban } \\
\text { not caused by } \\
\text { indiscriminate } \\
\text { waste } \\
\text { dumps/disposal. }\end{array}$ & 107 & 71.73 & 21 & 5.60 & 70 & 18.67 & 15 & 4.00 & 375 & 100 \\
\hline 4 & $\begin{array}{l}\text { The destruction of } \\
\text { the aesthetics, } \\
\text { blockage of roads } \\
\text { (streets) and water } \\
\text { channels in } \\
\text { Abakaliki urban } \\
\text { are not mostly } \\
\text { caused by heaps of } \\
\text { indiscriminate } \\
\text { solid wastes. }\end{array}$ & 84 & 22.40 & 81 & 21.60 & 100 & 26.67 & 110 & 29.33 & 375 & 100 \\
\hline
\end{tabular}

Source: Researchers’ field work, 2015.

\section{General Decision Rule}

If the calculated chi-square $\left(\mathrm{X}^{2}\right)$ value is greater than the critical value, that is, degree of freedom at 3 , the null hypothesis (Ho) is accepted as valid while the alternate hypothesis (HA) is rejected and vice versa. 
Expected frequency $(\mathrm{E}) \quad=\quad \frac{\text { Total no of Respondents }}{\text { No of responses options }}$

$$
\begin{aligned}
& =\quad \frac{375}{4} \\
& =\quad 93.8
\end{aligned}
$$

It should be noted that all mathematics were solved and summarized in the chi-square $\left(\mathrm{X}^{2}\right)$ table as follows:

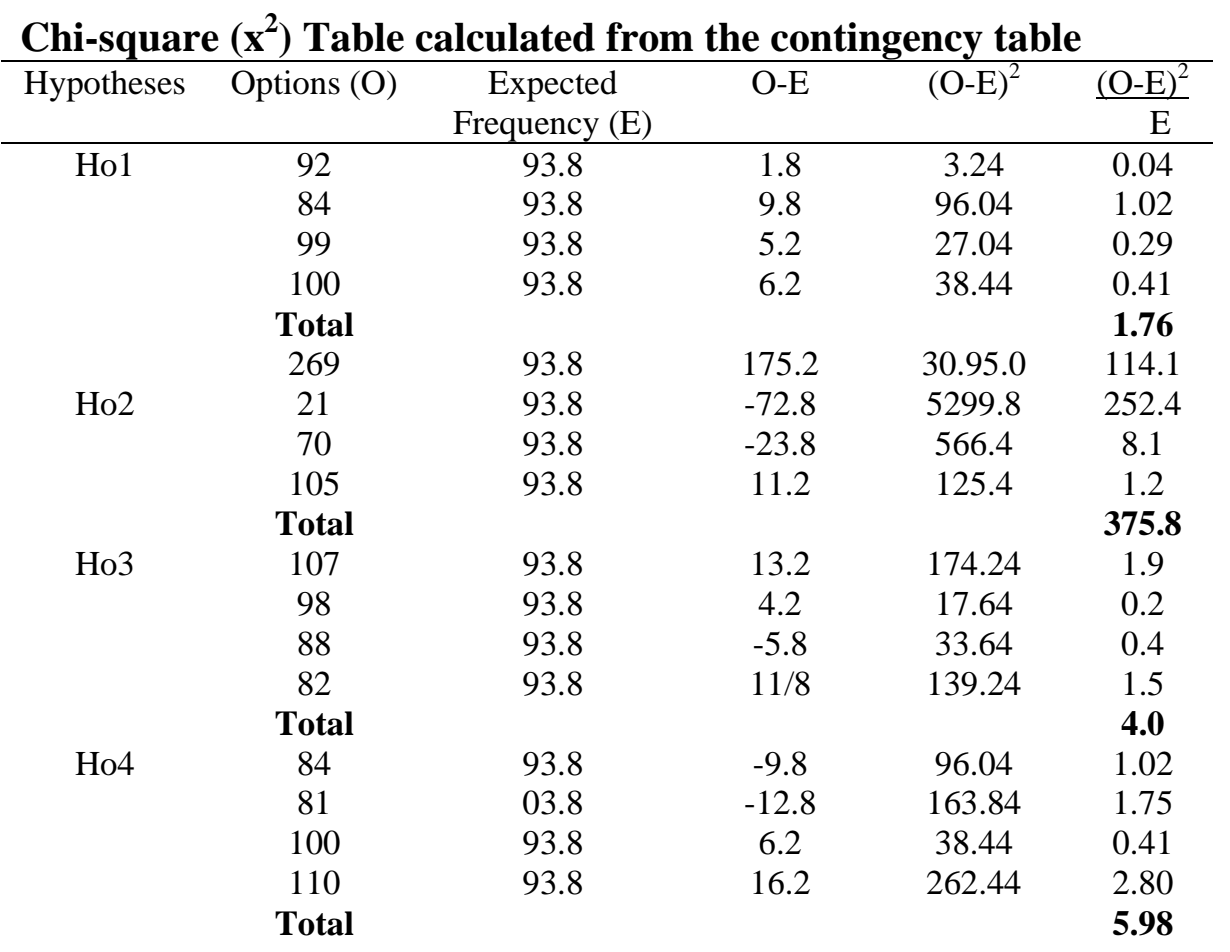

Source: Researchers' field work, 2015.

Therefore, the calculated chi-square $\left(\mathrm{X}^{2}\right)$ values are: $1.76,375.8,4.0$ and 5.98 for hypotheses 1, 2, 3 and 4 respectively.

To compute the degree of freedom (df) or critical value;

$\mathrm{df}=(\mathrm{R}-1)(\mathrm{C}-1)$

Where; $\quad \mathrm{R}=$ number of rows which is 4

$\mathrm{C}=$ number of columns which is 2

$=(4-1)(2-1)$

$=\quad(3)(1)$

$=3 \times 1$

$=3$

The researcher assumed 95\% level of confidence and 5\% level of significance. At 95\% level of confidence and 5\% level of significance, the degree of freedom (DF) at $3=7.815$ which is equal to 7.8 approximately. 
From the computations and in compliance to the general decision rule, the alternate hypothesis (HA1) was accepted while the null hypothesis (HO1) was rejected since the calculated chi-square $\left(\mathrm{X}^{2}\right)$ value, 1.76 is lesser than the degree of freedom at 3 which is 7.8. A lot of people from the computation believed that the lack of clear knowledge and skills to make solid wastes useful is the main reason for the persistent increases in the number of indiscriminate solid waste dumps in Abakaliki urban. Though other factors may have contributed but when solid wastes are made useful through proper management, people would be jealous of their wastes and would learn to dispose them appropriately to gain marginal utility from them.

The alternate hypothesis (HA2) which states that all the measures already put in place are capable if properly applied; of curtailing the tide of indiscriminate waste disposal/dumps in Abakaliki urban was rejected. This was in agreement with the general decision rule since the calculated chisquare $\left(\mathrm{X}^{2}\right)$ value which is 375.8 was greater than the critical value that is, the degree of freedom at 3 which is 7.8. The implication is that none of the measures already put in place to curtail the tide of indiscriminate solid waste disposal/dumps in Abakaliki is capable of doing so. This invariably, agrees with the conclusion from hypothesis one.

In a related development, the alternate hypothesis (HA3) which states that, most epidemic outbreaks in Abakaliki urban caused by waste was accepted as valid while the null hypothesis (Ho3) was rejected. This was because, the calculated chi-square $\left(\mathrm{X}^{2}\right)$ value, 4.0, is less than the degree of freedom or critical value at 3 which is 7.8. This means, without doubt, that most epidemic outbreaks in Abakaliki urban have always been caused by indiscriminate wastes that are poorly handled. Medical reports as revealed in table 8 are also pointers to this. Finally, the alternate hypothesis (HA4) which states that, the destruction of the aesthetics, blockage of roads (streets) and water channels are mostly caused by heaps of indiscriminate solid waste in Abakaliki urban was accepted as valid while the null hypothesis (HO4) which states that the destruction of the aesthetics, blockage of roads (streets) and water channels in Abakaliki urban, are not mostly caused by heaps of indiscriminate solid wastes was rejected. This was because, in agreement with our general decision rule without manipulation, the calculated chisquare $\left(\mathrm{X}^{2}\right)$ value which was 5.98 is less than the critical value/degree of freedom at 3 which is 7.8. This therefore means that, in no small measure, the destruction of the beauty, blocking of roads, streets or water channels which cause flooding are mostly caused by indiscriminate waste dumps/disposal in Abakaliki urban. 


\section{Summary of Findings}

In the course of presenting, analyzing and testing the hypotheses formulated for this study, the following findings as summarized were made:

1. There is no government approved permanent waste dumpsites anywhere in Ebonyi state including Abakaliki urban, to serve as final wastes collection points and residents do not help matters through their poor waste disposal habits. The most commonly repeated experience is the simple transfer of wastes from one unapproved site to another.

2. Government through EBSEPA and individuals has not made significant efforts to curtail the tide of indiscriminate solid wastes in Abakaliki urban despite the provisions of the EBSEPA's waste collection equipments.

3. Indiscriminate waste disposal/dumps in Abakaliki urban that are not in any way put into any good use (managed), significantly contribute to spreading avoidable communicable and other life threatening diseases.

4. EBSEPA as a waste management agency in Ebonyi state lacks the required modern equipment and technical competence to handle the ever increasing wastes in Abakaliki urban centre. A situation in which only 3 experts serve in environmental, pollution control and waste management in the Agency is a pointer.

5. The urban local governments (Abakaliki, Ebonyi and Izzi) have failed in their constitutional responsibilities of ensuring proper evacuation and disposal of urban solid wastes and Ebonyi state government currently seem to have no concrete plan to ensure proper waste management.

\section{Conclusion}

The findings of this study leave nobody in doubt about the devastating effects of urban solid waste in Abakaliki as a result of inappropriate and inadequate management. We therefore posit that both the individuals and the government through EBSEPA have not made appreciable efforts to get and train the required manpower with technical skills and competences that would nip the ever-increasing solid wastes in Abakaliki urban in the bud through proper generation, disposal, control, sorting and other management strategies, and should the current state of affairs in handling wastes in Abakaliki urban continue, the resultant negative consequences will have multiplier effects on the present and future inhabitants of the area. Government is therefore advised to sit up and treat Abakaliki urban solid wastes with the seriousness they deserve if it must keep faith with protecting the environment and lives of people in the area. 


\section{Recommendations}

In line with the findings of this study and its implications, the following recommendations were therefore made:

1. Ebonyi State Government through Ebonyi State should as a matter of urgent public importance, strengthen the already established department of Environmental and Public Health in the School of Health Technology, Ezzamgbo and the Faculty of Environmental and Health Sciences, Ebonyi State University (EBSU) Abakaliki by providing them with modern equipment including machines, for students to be exposed to practical methods of contemporary waste management.

2. Ebonyi State Government should partner with foreign-based waste management firm under public-private-partnership (PPP) arrangement to commence operation in Abakaliki. Such firm should at least be a specialist in any waste management operation including; generation, sorting/separation, recycling and conversion. The firm shall be encouraged to collaborate with EBSEPA staff to complement the manpower needs. The firm apart from serving as a source of revenue to the government will also serve as a training centre for Industrial Training (IT) students. They can also employ graduates of health and environmental related courses as suggested in number one. Government can afford to donate free land to such firm as a mark of commitment and seriousness. The services of the private sector (firms) that will operate day and night to complement EBSEPA's should be employed by the state government for the constant evacuation of the wastes to the permanent dumpsites that must be mapped out. The waste pulverization machines purchased by Ebonyi state should be leased to such firm for proper use. The waste management machines and/or plant should be stationed near the permanent dumpsites to be provided by the government.

3. Ebonyi State government should as a matter of urgent public importance, provide permanent waste dumpsites that must be far from markets, schools, churches, commercial and residential areas. This will at least, reduce the dangers of communicable and other life threatening diseases. This should be immediately followed with public enlightenments, symposia, workshops and seminars to sensitize residents on the modalities for generation and disposal of their wastes in the must-mapped out waste collection centres that must be increased beyond the current provisions of the EBSEPA equipments. Defaulters should be prosecuted to imprisonment or sentenced without an option of fine to serve as deterrent to others.

4. The landlords and other inhabitants of the state should be properly represented when planning for any waste minimization or management strategy.

5. Urban and regional planning should be encouraged. The Abakaliki Capital Territory Board should be the engine room for this. 
6. There is need for government sponsorship of environmental and waste management based-researches to serve as motivation to thinkers in that line.

7. $\quad$ Primary and secondary school curricula should include relevant and detailed topics on waste and its management.

8. The various media organizations including radio, television, magazines, and newspapers and so on should complement government's efforts to sensitize the residents on the dangers of dirty environment and the need to maintain good personal and environmental hygiene.

9. Urban local governments through the Ebonyi State House of Assembly legislation should be redirected and mandated to provide potions of land that would serve as permanent dumpsites and ensure that heaps of refuse are cleared on a daily basis to such sites.

10. Recruitment of more experts in environmental, pollution control and waste management into EBSEPA should be one of the priorities of the current government in Ebonyi State.

\section{References:}

Adejobi, O.S., and Olorunnimbe, R.O. (2012). "Challenges of waste management and climate change in Nigeria: Lagos State metropolis experience". African journal of Scientific Research vol. 7 No.1 @journalsbank.com (2012). Pp. 346-362

Agunwamba, S.O. (1998). "Solid waste management in Nigeria, problems and issues"; Journal of environmental management vol. 22 No. 6 pp 849856.

Akinbode, A. (2002). Introductory environmental resources management. Ibadan: Daybis publishers.

Asuquo, A.I., Kinuabeye, J.U. and Atu, J.E. (2012). “Attitude of urban dwellers of waste disposal and management in calabar, european journal of sustainable development vol 1, no. 1, pp 22-34.

Attah, M. (2013). Problems of domestic waste management in Nigeria: any repressors? University of Benin: faculty of law.

Bridgewater, A.K. (1980). Waste management in Europe van stand Reinhold @ Ltd England.

Butu, A.W. and Mshelia, S.S. (2014). "Municipal solid waste disposal and environmental issues in Kano metropolis Nigeria"; Britain Journal of Environmental Sciences vol.2, no.1, pp1-16, June 2014. Published by European centre for research training and development UK (www.eajournals.org).

Butu, A.W., Ageda, B.R. and Bichi, A.A. (2013). "Environmental impacts of roadside Disposal of Municipal Solid Waste in Karu, Narrasawa State 
Nigeria”. Internal journal of Environmental and Pollution Research vol. 1, no. 1 pp.1-19.

Ceridian UK Ltd (2007). “Human capital white paper” (PDF). Retrieved: 27/02/2007.

Chukwuemeka, E., Igwegbe, D. and Ugwu, J. (2012). Management and Development Implications of Solid Waste Management in Nigeria. Asian Journal of Business Management (C) madkwell Scientific Organization, 2012 edition vol 4 pp. 352-358.

Dimuna, K.O. (2004). "The Problem with the Management of Environmental Pollution in Nigeria”; journal of applied and basic science, vol2 no.1 and 2 pp. 5-9.

Diribe, C.O. (1990). Major environmental problems and their impacts in Enugu state, Enugu State Environment Action Plan.

Edu, N. (2003). Environmental waste and management, Calabar: Ushie printers and publishing ltd.

Emeribe, A.C. (2000). Environment solid waste management for sustainable development in Nigeria: some new perspectives, policy and contending issues in Nigerian national development strategy, Enugu john Jacobs classic publishers.

Ezeani, E.O. and Elekwa, N.N. (2001). Issues in Urbanization and Urban Administration in Nigeria, Enugu. Jamoe enterprises (Nigeria).

Federal Environmental Protection Agency (1989). National Policy on the Environment. Federal Republic of Nigeria.

Federal Republic of Nigeria (FRN) (1990). National Environmental Sanitation Lessons for states. Lagos: government publications.

Federal Republic of Nigeria (1999), “The Constitution”, Abuja: Government Press.

Isaac, I.M., and Olamike, S. O. (2007). Waste management in emerging cities, any solution? Aba: Great Ventures Ltd.

Jimoh, I.A. (2005). A new approach to municipal waste management in Nigeria, international conference on energy; environment and disasters. USA: charlotte N.C.

Madu, I.A. (2001). "Urban solid waste problem in Nigeria”, in Ezeani, E.O. and Elekwa, N.N. (eds). Issues in urbanization and urban administration in Nigeria, Enugu: Jamoe enterprise (Nigeria).

Mba, S.O. (2003). Fundamentals of Public Health for the Tropical: Personal and Community Perspectives. Owerri: Oni Publishers.

Momodu, N.S., Dimuna, k. O. and Dimuna, J.E. (2011) "Mitigating the Impacts of Solid Wastes in Urban Centres in Nigeria”, Journals of Human and Ecological Sciences vol 134 no. pp 125-133.

Ndinwa, C.C. G., Akpafun, A.S., Chukwuma, C.O. and Nwakaego, P. (2012). "Improving Municipal Waste Disposal through Integrated Waste 
Management the Southern Nigeria Experience”; Journal of Environmental Sciences and Resource Management vol. 4, Cenresin Publications.

Nabegu, A.B. (2013). An Analysis of Municipal Solid Waste in Kano Metropolis, Nigeria: A Paper Presented in a Workshop at Kano State University of Science and Technology, Wudil on $12^{\text {th }}$ July.

Ngoka, I.H. (2001). Environmental pollution and industry: a case study of Nnewi Town, Unpublished B.Sc Thesis, Department of Geography, University of Nigeria, Nsukka.

Nkwede, J.O. (2001). “Environmental Protection in Nigeria’s cities: A Critical Assessment of Ebonyi State Environmental Protection Agency (EBSEPA)”, in Ezeani, E.O. and Elekwa, N.N. (eds), Issues in Urbanization and Urban Administration in Nigeria, Enugu: Jamoe Enterprises (Nigeria).

Nkwede, J.O. and Nwuzor, C.I. (2015). Strategies for urban waste management and employment creation in Nigeria: a study of Ebonyi State Environmental Protection Agency (EBSEPA), paper presented at a conference in Kennesaw state university, Georgia, USA from 17-18 ${ }^{\text {th }}$ April. Nwokocha, G. (2012). Managing household solid waste, Onitsha J.D. publication.

Nwude, M.O. (2006). A sustainable option for solid waste management in Kaduna metropolis. Unpublished M.Sc thesis.

Nwude, M.O., Igboro, S.B., Umar, I. and Okuofu, C.A., (2008). Evaluation of solid waste Management in Kaduna Metropolis, Nigeria; Kaduna: Ahmadu Bello University.

Ogwueleka, T.C. (2009). "Municipal Solid Waste Characteristics and Management in Nigeria”, Iran Journal of Environmental Health Sciences, vol 6 no. 3 pp 173-180.

Okpala, J. (1997). Problems of solid household waste disposal in Nigeria, Ibadan: Tomide production.

Okpala, N. (1986). "Changing perspectives of solid waste management in Anambra State”, Journal of Environmental Studies. 2(1) 45-51.

Ologbobo, A. (1997). Strategies for efficient waste disposal in Nigeria, in Okali, D. etal (eds) perspectives in environmental management. Proceedings of nest annual workshops 1991-1995. Nest Ibadan pp. 119-124.

Onwughara, I.N., Nnorom, I.C., and Kanno, O.C. (2010). "Issues in Roadside Disposal Habit of Municipal Solid Waste Environmental Impacts and Implementation of Sound Management Practices in Developing Country "Nigeria”, International Journal of Environmental Sciences and Development vol. 1, No.5.

Oxford Advanced Learner's Dictionary (1998). Special Price Edition. England: Oxford University press.

Oyediran, A.B.O.O. (1997). "Waste Generating and Disposal in Nigeria: A Keynote Address”, in Okali, D. et al (eds) Perspectives in Environmental 
Management Proceedings of Nest Workshops 1991 to 1995, Nest Ibadan pp 95-100.

Oyeniyi, B.A. (2011). "West Management in contemporary Nigeria: the Abuja example”. Netherlands: International Journal of Politics and Good Governance. vol. 2, no. 22, pp 1-18.

Phil-Eze, P.O. (2001). "Urban Environmental problems in Nigeria”, in Ezeani, E.O. and Elekwa, N.N. (eds). Issues in urbanization and urban administration in Nigeria, Enugu: Jamoe enterprises (Nigeria).

Rodgers, M. (2011). Fundamentals of development administration. London: S.K. publishers.

Scott, M.J. (1996). Human Settlements in a Changing Climate: Impacts and Adaptation, England: Cambridge University Press.

Sharma, B.K. (2010). Environmental chemistry. Goal publishing house, Mearut pp 101-1018.

Sridhar, M.K.C. (2006). "From Urban Waste to Sustainable Waste Management in Nigeria. a Case study, in M.F.A. Ivbijaro, F. Akintola, and R.U. Okechukwu (eds), Sustainable Environmental Management in Nigeria; Ibadan: Mattivi productions.

Sridhar, M.K.C. and Hammed, T.B. (2014). Turning Waste to Wealth in Nigeria: An overview. Ibadan: college of Medicine.

Sule, R.O. (2001). Urban environmental pollution, a critical assessment: a synopsis published by Baaj international company, Ibadan/Benin.

Sule, R.O.I. (2004). Solid and fecal waste disposal urban development planning framework: the Nigeria Experience; Nigeria: Thumbprint International Company.

Tobore, I.E. (2013). Solid Waste Management in Nigeria; International Solid Wastes Association.

Uka, F. (2013). Ebonyi to partner US-based Firm on Waste Management. Citizens Advocate, November 7, 2013. Retrieved, 10 ${ }^{\text {th }}$ Dec. 2013.

United Nations Secretariat (1970). Globalization and urbanization in the $3^{\text {rd }}$ world countries. Washington DC: UN Publication.

United Nations Environmental Programme (UNEP) (1988). Industry and Environment. volume vi no 1. 